Portland State University

PDXScholar

\title{
Iron-Deficiency Anaemia (IDA): Socio-Cultural Misconceptions Intersect the Health of Vulnerable Populations in Developing Countries
}

Samantha G. Alarcon Basurto

Portland State University

Follow this and additional works at: https://pdxscholar.library.pdx.edu/honorstheses

Part of the Community Health and Preventive Medicine Commons, and the Maternal and Child Health Commons

Let us know how access to this document benefits you.

\section{Recommended Citation}

Alarcon Basurto, Samantha G., "Iron-Deficiency Anaemia (IDA): Socio-Cultural Misconceptions Intersect the Health of Vulnerable Populations in Developing Countries" (2020). University Honors Theses. Paper 840.

https://doi.org/10.15760/honors.859

This Thesis is brought to you for free and open access. It has been accepted for inclusion in University Honors Theses by an authorized administrator of PDXScholar. Please contact us if we can make this document more accessible: pdxscholar@pdx.edu. 


\title{
Iron-Deficiency Anaemia (IDA): Socio-Cultural Misconceptions Intersect the Health of Vulnerable Populations in Developing Countries
}

\author{
Authored by: \\ Samantha G. Alarcon Basurto \\ An Undergraduate Honors Thesis submitted in partial fulfillment of the requirements for a \\ Bachelor of Arts \\ degree from \\ Portland State University Honors College \\ and \\ The School of Public Health \\ in \\ Health Studies: Community Health Promotion
}

Thesis Adviser:

Dr. Shawn Smallman

Portland State University

May 23rd, 2020 


\section{Dedication}

"To my supportive family, Tamara, Franco, Mirtha and Martin, who from kilometers away still managed to keep me on track writing this thesis. To my godfather, Lenin, who consistently updated me on the incidence of anemia in Peru. To my partner, Ian, who listened to my never-ending writer's crises and endlessly made tea to keep me awake to write. To my thesis advisor, Shawn, my biggest cheerleader and coach throughout the thesis process. And to my beloved roommates, Claire, Zoe, Maritsa, Bella, and Eduardo, for helping me edit and remind me that I've got a family of scholars ready to back me up". 


\begin{abstract}
Iron is a mineral that the human body uses to make hemoglobin, a protein that red blood cells need to carry oxygen from the lungs to all parts of the body. The lack of adequate iron in the blood is known as iron deficiency, which if experienced in greater proportions, can lead to anaemia. Iron-deficiency anaemia is generally understood as a nutritional deficiency that can be treated with a diet of iron-rich foods or the ingestion of iron supplements; yet lack of information, restricted access to bioavailable iron-rich foods, minimal awareness of anaemia's detrimental effects on childrens' cognitive development, culturally inaccurate understandings of anaemia's consequences, and prevalence of non-compliance regarding supplemental intervention among pregnant women illuminate a public health issue of the developing world that is greater than simply focusing on the mass distribution of iron supplements. A holistic and culturally-driven perspective of iron-deficiency anaemia is necessary for adjusting our current practices of health counseling, distribution of complete information regarding iron supplements, informed and culturally-sensitive diets, as well as ensuring the delivery of substantial preventative and follow-up programs for treating iron-deficiency anaemia.
\end{abstract}

Keywords: iron, iron-deficiency anaemia, developing countries, pregnant women, cognitive development, first and second tier hospitals, multisectorial plan, culturally-sensitive. 


\begin{abstract}
o
El hierro es un mineral que el cuerpo humano utiliza para crear hemoglobina, proteína que glóbulos rojos necesitan para llevar oxígeno a los pulmones y a todas las partes del cuerpo. La falta de hierro en la sangre se considera una deficiencia nutricional, la cual experimentada en mayores proporciones es capaz de provocar una anemia. Generalmente dicha condición es tratada utilizando una dieta rica en hierro, así como también implementando la ingestión de suplementos de hierro. Sin embargo, la falta de información, el acceso restringido a un dieta biodisponible en hierro, el conocimiento mínimo de los efectos perjudiciales en el desarrollo cognitivo de los niños, la comprensión cultural inexacta de las consecuencia de la anemia, y el incumpliento de la ingestión de píldoras de hierro; apuntan a un problema mucho más grande, presente en la salud pública de países subdesarrollados el cual pasa desapercibido. El porcentaje de personas que padecen de insuficiencia de hierro sugiere que el problema no radica en la falta de suplementos de hierro, sino en un concepto impreciso de cómo tratar la anemia. Una perspectiva integral y culturalmente orientada es necesaria, para ajustar nuestras prácticas actuales de asesoramiento de la salud, para la distribución e información completa de suplementos de hierro, para proveer dietas informadas y culturalmente sensibles, y para la creación de programas sustanciales de prevención y seguimiento de la anemia por deficiencia de hierro.
\end{abstract}

Palabras Clave: hierro, anemia por deficiencia de hierro, países subdesarrollados, mujeres embarazadas, desarrollo cognitivo, plan multisectorial. 
Iron-Deficiency Anaemia (IDA): Socio-Cultural Misconceptions Intersect the Health of Vulnerable Populations in Developing Countries

Despite vast scientific knowledge around identifying essential nutrients for the body to function, improved nutritional patterns, and the availability of low-cost oral iron supplements, iron deficiency anaemia (IDA) remains one of the most pressing public health issues worldwide, affecting vulnerable populations at disproportionate rates. The World Health Organization (2015) estimates that anaemia affected 800 million children and women in 2011, with approximately $50 \%$ of anaemia cases considered to be a product of iron deficiency. The majority of the burden of anaemia is concentrated in the Southern Hemisphere, territory occupied by developing countries. While developed countries have an estimated $9 \%$ of anaemia cases, developing countries suffer anaemia at a rate of approximately $43 \%$. Indeed, anaemia is not distributed evenly throughout the world, as indicated by the fivefold increase seen in underdeveloped geographies (Miller, 2013).

Human development is an important factor when discussing anaemia prevention strategies. Pregnancy, growth spurts, and blood loss due to menstruation, lead to iron shortage in the body, requiring the body to produce more red blood cells than usual to compensate for the fast-paced iron usage needed for proper development (NHLBI, 2011). In the course of a pregnancy, the fetus's rate of growth occurs early in the second trimester. It is in these beginning stages of pregnancy when iron stores must be fully replenished in order to meet the exponential iron demands of the growing fetus. If iron demands are not fully met by the mother, defects in cognitive development may occur in the child. 
Two methods of preventing and treating IDA exist: iron supplementation (i.e. iron pills) and iron fortification (i.e. iron fortified foods). The notion that the provision of iron pills to treat and prevent anaemia is beneficial is not incorrect, but its effectiveness has been overestimated and poorly misguided since the burden of IDA is still a prevalent health issue around the globe. Lack of attention ascribed to this devastating condition is what ultimately sparked my research, shedding light on the social conditions of iron deficiency anaemia. The research question I attempt to answer is the following: Why is iron-deficiency anaemia still a public health issue for developing countries, despite the advancements of medical diagnosis and availability of iron supplements? I argue that iron deficiency should be analyzed under the lens of the social determinants of health, where public health officials accept that an intervention strategy cannot solely rely on the distribution of iron supplements. A holistic and culturally-tailored approach is required to comprehend why IDA is still a challenge to the overall health of developing countries.

The structure of this paper is meant to instruct and expose the reader to diverse forms of IDA representation and its major repercussions. Out of the four groups at risk described, I will particularly focus on pregnant women. The literature reviewed argues that diverse factors enable the onset of anaemia: behaviors around diet, health practices and diagnosis, infectious diseases, pregnancy and parity, biological development, and misconceptions of the condition. The paper culminates with a case study performed in a first and second tier hospital of Lima, Peru, where thirteen midwives were interviewed about their health practices and personal opinions on what elements and circumstances drive iron deficiency anaemia among Peruvian pregnant women. 


\section{Background}

Iron is a mineral that the body needs for growth and development $(\mathrm{NIH}, 2019)$. The body uses iron to make hemoglobin, which is a protein in red blood cells (RBCs) that carry oxygen from the lungs to all parts of the body. The amount of iron needed for the human body to function is based on "your age, your sex, and whether you consume mostly a plant-based diet" (NIH, 2019). The consumption of low iron in your diet, menstruation cycles, pregnancy, post-pregnancy, and periods of growth and development impacts iron levels and most of the time it requires an adequate amount of iron storage. Almost two thirds of the iron is found in hemoglobin (Millman, 2011,pg.369), thus a lower-than-normal hemoglobin concentration can lead to iron-deficiency, and subsequently to iron-deficiency anaemia.

There are many types of anaemia such as "iron-deficiency anaemia, pernicious anaemia, aplastic anaemia, and hemolytic anaemia" (NHLBI, 2011), however, IDA is by far the most important, causing approximately " $75-80 \%$ of the total burden of anaemias" (Millman, 2011, pg.370). The decreased and faulty production of RBCs is a worldwide illness affecting populations disproportionately, with the highest percentage of people affected in developing countries (Kadivar, 2003). Ironically, IDA can be preventable (NHLBI, 2011), but it is often not successfully treated or prevented (U.S. Department of Health and Human Services, 2018).

\section{IRON-DEFICIENCY ANAEMIA}

The main way the body gets iron is from food (NHLBI, 2011). Individuals that follow a meat-based diet are not as susceptible to become iron deficient. Eating foods fortified with iron is also another way to enrich your diet, but it all comes down to access and bioavailability of iron 
in the foods one consumes. Communities living in poverty have limited access to the previous iron channels, which is coupled with a lack of awareness of food-iron inhibitors.

Most cases of anaemia are due to iron deficiency, which often "work in symphony with folate deficiency and/or vitamin B12 deficiency as well as with infections" like malaria and hookworm, and birth defects like sickle cell and thalassemias. In developing countries "folate deficiencies occurs in as many as $25 \%$ to $72 \%$ of women of reproductive age" and if the factor factor of living in a tropical area with poor sanitary conditions exposed to malaria and hookworms is added, the burden of IDA is even higher (Millman, 2011, pg.369).

IDA is classified in three evolving stages, as the following:

"The first phase is the depletion of storage of iron, however, even though the total body has decreased hemoglobin and red blood cells remain unaffected. The second phase is when the supply of iron to bone marrow becomes a problem by causing erythropoiesis. The third phase occurs when the iron supply is insufficient to maintain a normal level of hemoglobin concentration, and eventually this last stage leads to iron-deficiency anaemia"

(Chung et al., 2013).

The phases can also be understood as being mild, moderate, and severe anaemia. In this sense, the majority of the population would be diagnosed with mild-to-moderate anaemia, and just a specific proportion of patients are identified with severe anaemia. It is important to pay attention to the phases of anaemia when creating an intervention, because in the initial phase the first step should be to institute a change in diet to increase iron storage. Comparatively, for individuals 
with severe anaemia treatment might have to go even further, and they may begin to think about blood transplants. The stage of the patient is also important, for example, a pregnant woman with a growing fetus is going to need a greater amount of bioavailable iron.

Multiple studies show that the measurement of ferritin levels are directly proportional to the total iron in the body. However, "its synthesis increases in the presence of inflammatory or malignant diseases" produce a false elevation of ferritin while iron stores can still be low or absent (Denic \& Agarwal, 2007, pg. 604). The limited medical resources and undertrained staff to diagnose IDA presents a greater disadvantage when determining who constitutes the at-risk population in need of iron. Furthermore, the lack of equipment and gaps in knowledge might also act as obstacles when diagnosing IDA. This is especially the case for groups at risk: infants and children, adolescents, women of childbearing age, pregnant women, and postpartum women.

Timing is an important factor when diagnosing for IDA because during certain stages - pregnancy, growth spurts, or blood loss — the body needs to make more red blood cells than usual to compensate for the fast-paced iron usage needed for a proper development (NHLBI, 2011). For instance, "the neural tube is formed within approximately 30 days after conception", making it essential for pregnant women to have a good folate status prior to conception, and during the gestation period (Millman, 2011, pg.375). Then again, iron-deficiency is developed if the body cannot keep up with its need for iron, even though it is known that in the absence of hemorrhage "anaemia generally develops slowly over the course of months or years" (Miller, 2013, pg.2). It is important to note that iron-deficiency (ID) and iron-deficiency anaemia should not be used synonymously as they both stand for different levels of iron in our bodies. However, it is known that the latent stage of ID usually leads to IDA. As a 
matter of fact, attempts to prevent the onset of iron deficiency would also work to decrease the numbers of people diagnosed with iron-deficiency anaemia in the long-run.

\section{EFFECTS ON GROWTH AND DEVELOPMENT}

The usual symptoms of iron-deficiency anaemia include GI upset, weakness, tiredness, lack of energy, and problems with concentration and memory. Infants and children who have IDA could even develop learning difficulties (NIH, 2019). The most challenging disadvantages are faced during periods of growth and development, since during the duration of IDA "the developmental trajectory may be put on hold, progress more slowly or out of synchrony, causing a delay or disruption in brain development” (Lozoff et. al, 2006, pg. 40). Timing again plays a role, because it is more important to have iron delivery during early brain development than ultimately reaching the normal concentrations of iron after the growth spurt has already happened.

Studies have shown that "the reversibility of cognitive defects caused at an early age by iron deficiency is unclear" especially if it's not treated in pregnant females. Consequences might be passed to their infant/newborn (Miller, 2013, pg.6). For example, if IDA is present, then the second trimester of pregnancy (weeks 13 - 26) is associated with anthropometric Z-scores - helps evaluate children's growth and nutritional status - Moreover, if IDA is present at the third trimester of pregnancy (week 27 to the end of pregnancy) it is associated with orientation NBAS (Neonatal Behavioral Assessment Scale) cluster scores, which focus on the measurement of the infant's quick behavioral responses (Menon et. al, 2016). The results of the study concluded that IDA during pregnancy scores lower on the anthropometric Z-scores and the orientation NBAS compared to children born from non-anaemic women. Additionally, the "peak 
growth velocity occurs during the early second trimester followed by a gradual decline to the third trimester" (Menon et. al, 2016, pg. 63), providing information that it is at the beginning stages of pregnancy that iron stores need to be fully replenished to meet the exponential iron demands of the growing fetus.

Several case-control studies have compared healthy full-term infants with IDA infants which resulted in data illustrating lower iron status among the IDA infants, also visible in "mental development test scores averaged 6 to 15 points lower" compared to healthy infants (Lozoff et. al, 2006, pg. 34). IDA infants already find themselves at a greater cognitive disadvantage from an early stage of life, and the overall development is also triggered by "poor recognition memory" (Lozoff et. al, 2006, pg. 39) when IDA hits the hippocampus, which affects other components of the nervous system as well.

The impact caused by IDA among young children is carried into adulthood due to the repercussions of the impaired learning capacity, cognitive performance, and psychomotor development that impact worker productivity. Equally, evidence generated through analysis indicates that for every $10 \%$ increase in hemoglobin concentration, a $15 \%$ improvement in worker productivity of anemic laborers was expected (Cook, 1994; Levis 1986).

An easy fix would be the delivery of iron supplements to the entire population affected with IDA, however, such a fix is not as simple as it seems. Receiving an accurate diagnosis that determines the stage or non-stage of IDA is important prior to the ingestion of iron supplements, since too much iron in the body can be harmful, as well as clinically understood to cause death in some cases. To emphasize, "high doses of iron can decrease zinc absorption, however, extremely high doses of iron can cause organ failure, coma, convulsions, and ultimately death" 
(NIH, 2019). Additionally, the great majority of developing countries do not tend to have the latest medical tools to test for IDA and misdiagnosis could lead to an additional case of fatality, due to an overdose of iron supplementation.

\section{BURDEN OF “IDA” AND ITS MAJOR RISK GROUPS}

As identified by Millman (2011) the major risk groups experiencing the burden of IDA are young children (under-5 years of age), adolescent females (non-pregnant women of reproductive age who lose iron through their menstruation cycles), pregnant women (who have an increased need of iron for the growing fetus), and postpartum women ( women currently lactating).

\section{NEWBORN INFANTS AND YOUNG CHILDREN}

In part due to their physiological vulnerability and constant growth and development, are at a high risk of developing IDA. The percentage of children under 5 years of age with a hemoglobin concentration less than $110 \mathrm{~g} / \mathrm{L}$ (before developing mild anaemia) is $59.71 \%$ for the African region, followed by $51.61 \%$ for the South-East Asia region, and $45.32 \%$ for the Eastern Mediterranean region, adjusted for altitude (see Table 3). Not surprisingly, the fetus and newborn infant's iron status depends on the iron status of the mother, and therefore, "iron deficiency in the mother-to-be means that the growing fetus will probably be iron-deficient as well” (Millman, 2011, pg. 372). However, this relationship has received very little attention due to the fact that infants are protected if the mother is not experiencing acute anaemia or severe anaemia. Nonetheless, children who have IDA, presumably due to anaemia during infancy "continue to perform less well than peers who had good iron status during infancy" (Lozoff et.al, 2006, pg. 37). 


\section{ADOLESCENT FEMALES}

Adolescent women, women who are non-pregnant and of reproductive age, are at a high risk of developing IDA due to the loss of iron during their menstruation cycles, developmental periods of growth, and changes in diet to attain a slimmer body. It is therefore estimated that "the combination of these three factors (growth, iron losses, and dietary habits) make them more vulnerable to develop iron deficiency, and consequently IDA”(Millman, 2011, pg.372). The percentage of anaemia among women of reproductive age less than $120 \mathrm{~g} / \mathrm{L}$, adjusted for altitude and smoking, indicates a higher prevalence in South-East Asia with 45.3\%, followed by Eastern Medierranean with 39.09\%, and Africa with 38.8\% (see Table 4). Although, there is not a significant difference in the prevalence of anaemia among non-pregnant women (Table 5), aside from a small variation in the decimals, yet the order of the regions with the highest prevalence follow the trend observed in Table 4. Furthermore, when an iron-deficient woman or a woman with IDA becomes pregnant, both the "prevalence and the severity of IDA may increase remarkably during pregnancy" unless treatment is available (Millman, 2011, pg.372). This indicates that it would be beneficial for women of a reproductive age to check their iron stores before conception, "to ensure an adequate micronutrient status during early stages of gestation,"(Menon et. al, 2016) as pregnancy requires higher levels of iron for adequate development of the fetus.

\section{PREGNANT WOMEN}

Pregnant women diagnosed with IDA are exposed to significant negative influences on the outcome of their pregnancy, since IDA causes a "higher risk of complications at delivery, a higher risk of early preterm deliveries, and a higher risk of delivering premature children with 
low-birth weight for their gestational status” (Millman, 2011, pg.373). In addition to the fetus's higher demand for iron stores from the mother, the "fetal iron demands are prioritized over the red cell mass of the mother," (Miller, 2013, pg. 5) leaving the mother with even lower iron stores, which results as an obstacle during breastfeeding stages. The percentage of pregnant women diagnosed with anaemia is less than $110 \mathrm{~g} / \mathrm{L}$, adjusted for altitude and smoking, is higher in South-East Asia with 47.92\%, followed by Africa with 46.34\%, and Eastern Mediterranean with $40.57 \%$ (see Table 6). Research studies suggest that "infants of women who were not anemic at 13 to 22 weeks gestation (i.e. at the second trimester) were $0.26 \mathrm{SD}$ heavier, $0.50 \mathrm{SD}$ taller, and had 0.26 SD larger head circumference compared to infants of anemic women," to the same point, infants of women who were not anemic in the third trimester had "orientation scores 3.88 higher than infants of anemic women" (Menon et. al, 2016, pg. 63). These findings suggest that IDA affects growth and cognitive development of the fetus when iron stores are low in pregnant women, and sometimes this partial neurobehavioral and cognitive deficit can be “irreversible or partially reversible" (Menon et. al, 2016,pg. 61).

\section{POSTPARTUM LACTATING WOMEN}

Postpartum lactating women diagnosed with IDA is a partially unrecognized problem in many parts of the world, however, there is a "direct link from IDA in pregnant women to IDA during postpartum;" therefore, the prevention of postpartum anaemia means also preventing prepartum anaemia (Millman, 2011, pg.373). In other words, we should be concentrating our efforts on women of reproductive age. Furthemore, given that breast milk is the main source of food for the baby for several months, the "quality and quantity of breast milk relies on a proper nutritional status of the mother" (Millman, 2011,pg.373). Additionally, mother's milk contains iron but it is 
tightly bound to lactoferrin — a protein found in the human body that attaches to iron — and thus iron in breast milk becomes harder for the infant to absorb. In this case, if infants are "fed only with mother's milk, they predictably develop iron deficiency within 6 months" (Denic \& Agarwal, 2007, pg. 608).

\section{PREVALENCE OF "IDA" WORLDWIDE}

Most recent data from the World Health Organization (2015) estimates that anaemia in 2011 affected 800 million children and women, and approximately 50\% of anaemia cases were considered to be a product of iron deficiency. Anaemia as a result from iron-deficiency is associated with low-birth weight and increased probability of maternal mortality. Further estimations attribute 90,000 deaths in both sexes and across all age groups to iron deficiency alone. The prevalence of IDA translates into " 273.2 million children, 496.3 million non-pregnant women, and 32.4 million pregnant women, giving a total of 528.7 million women of reproductive age with anaemia worldwide in 2011" (see Tables 1 and 2). Moreover, severe anaemia — associated with worse cognitive and functional outcomes_accounts for 9.6 million children and 20.2 million women of reproductive age (WHO, 2015).

The concentration of lowest blood hemoglobin and highest prevalence of anaemia varies considerably between regions and countries. Comparatively, in the case of the African region alarming data from "children aged 6-59 months with the lowest hemoglobin level averaged at $104 \mathrm{~g} / \mathrm{L}$ and the highest proportion of individuals with anaemia at $62.3 \%$, accounting for 84.5 million of children in 2011" (see Table 1).

Table 1. Global and WHO regional mean blood hemoglobin concentration and prevalence of anaemia among children aged 6-59 months in 2011 


\begin{tabular}{|c|c|c|c|c|c|}
\hline WHO Region & $\begin{array}{c}\text { Mean blood } \\
\text { hemoglobin } \\
\text { concentration } \\
(\mathrm{g} / \mathrm{L})\end{array}$ & $\begin{array}{c}\text { Percentage of } \\
\text { population } \\
\text { with anaemia }\end{array}$ & $\begin{array}{l}\text { Number of } \\
\text { people with } \\
\text { anaemia } \\
\text { (millions) }\end{array}$ & $\begin{array}{l}\text { Percentage of } \\
\text { population with } \\
\text { severe anaemia }\end{array}$ & $\begin{array}{c}\text { Number of } \\
\text { people with } \\
\text { severe anaemia } \\
\text { (millions) }\end{array}$ \\
\hline African Region & $104(103$ to 105$)$ & $62.3 \%$ & 84.5 & $3.6 \%$ & 4.9 \\
\hline $\begin{array}{l}\text { Region of the } \\
\text { Americas }\end{array}$ & $119(117$ to 121$)$ & $22.3 \%$ & 17.1 & $0.2 \%$ & 0.18 \\
\hline $\begin{array}{l}\text { South-East } \\
\text { Asia Region }\end{array}$ & $107(104$ to 112$)$ & $53.8 \%$ & 96.7 & $1.5 \%$ & 2.7 \\
\hline $\begin{array}{l}\text { European } \\
\text { Region }\end{array}$ & 109 (115 to 122$)$ & $22.9 \%$ & 12.7 & $0.3 \%$ & 0.2 \\
\hline $\begin{array}{l}\text { Eastern } \\
\text { Mediterranean } \\
\text { Region }\end{array}$ & $120(106$ to 112$)$ & $48.9 \%$ & 35.8 & $2.0 \%$ & 1.5 \\
\hline $\begin{array}{l}\text { Western } \\
\text { Pacific Region }\end{array}$ & $120(114$ to 125$)$ & $21.9 \%$ & 25.7 & $0.2 \%$ & 0.2 \\
\hline Global & $111(110$ to 113$)$ & $42.6 \%$ & 273.2 & $1.5 \%$ & 9.6 \\
\hline
\end{tabular}

Note: Graph of global and WHO regional mean blood hemoglobin concentration and prevalence of anaemia among children aged 6-59 months in 2011. "Reprinted from WHO. The global prevalence of anaemia in 2011," by WHO, 2015. Reprinted with permission.

Table 1 shows South-East Asia, Eastern Mediterranean and Africa with the lowest hemoglobin concentrations that translates into the highest prevalence of anaemia among their population. The mean blood hemoglobin concentration in these three regions goes from 104 to $109 \mathrm{~g} / \mathrm{L}$, with more than half of the cases concentrated among South-East Asia and Africa. Further, severe anaemia is highest in Africa concentrated among 4.9\% of the population of children aged 6-59 months (WHO, 2015).

As for all women of reproductive age (non-pregnant women, pregnant women) in 2011, the WHO estimated $29.4 \%$ prevalence of anaemia despite their hemoglobin concentration being higher than that of children under 5 years of age (see Table 2).

Table 2. Global and WHO regional mean blood hemoglobin concentration and prevalence of anaemia among all women of reproductive age (15-49 years) in 2011 


\begin{tabular}{|c|c|c|c|c|c|}
\hline WHO Region & $\begin{array}{c}\text { Mean blood } \\
\text { hemoglobin } \\
\text { concentration } \\
(\mathrm{g} / \mathrm{L})\end{array}$ & $\begin{array}{l}\text { Percentage of } \\
\text { population } \\
\text { with anaemia }\end{array}$ & $\begin{array}{c}\text { Number of } \\
\text { people with } \\
\text { anaemia } \\
\text { (millions) }\end{array}$ & $\begin{array}{l}\text { Percentage of } \\
\text { population with } \\
\text { severe anaemia }\end{array}$ & $\begin{array}{c}\text { Number of } \\
\text { people with } \\
\text { severe anaemia } \\
\text { (millions) }\end{array}$ \\
\hline African Region & $123(120$ to 125$)$ & $38.6 \%$ & 19.1 & $1.8 \%$ & 3.6 \\
\hline $\begin{array}{l}\text { Region of the } \\
\text { Americas }\end{array}$ & 131 (128 to 133$)$ & $16.8 \%$ & 40.5 & $0.5 \%$ & 1.3 \\
\hline $\begin{array}{l}\text { South-East } \\
\text { Asia Region }\end{array}$ & $121(117$ to 125$)$ & $41.9 \%$ & 202.0 & $1.8 \%$ & 8.9 \\
\hline $\begin{array}{l}\text { European } \\
\text { Region }\end{array}$ & $128(125$ to 130$)$ & $22.6 \%$ & 50.2 & $0.6 \%$ & 1.4 \\
\hline $\begin{array}{l}\text { Eastern } \\
\text { Mediterranean } \\
\text { Region }\end{array}$ & $122(120$ to 125$)$ & $37.8 \%$ & 59.1 & $1.8 \%$ & 2.7 \\
\hline $\begin{array}{l}\text { Western } \\
\text { Pacific Region }\end{array}$ & 129 (124 to134) & $19.9 \%$ & 96.2 & $0.5 \%$ & 2.3 \\
\hline Global & $125(125$ to 127$)$ & $29.4 \%$ & 528.7 & $1.1 \%$ & 20.2 \\
\hline
\end{tabular}

Note: Graph of global and WHO regional mean blood hemoglobin concentration and prevalence of anaemia among all women of reproductive age (15-49 years) 2011. "Reprinted from WHO. The global prevalence of anaemia in 2011," by WHO, 2015. Reprinted with permission.

Table 2 shows the highest prevalence of anaemia among populations of South-East Asia, Eastern Mediterranean, and Africa. With the majority of reproductive women with severe anaemia concentrated in the South-East Asia region with 8.9 million, followed by the African region with 3.6 million women with severe anaemia (WHO, 2015).

From the previous tables (Tables 1 and 2), a pattern has been established identifying the regions where the majority of vulnerable populations are affected by anaemia and severe anaemia based on the data calculated for millions of people. The majority of the burden of anaemia is concentrated in the South Hemisphere, essentially territory occupied by developing countries. Additionally, "the prevalence of anaemia is estimated to be at $9 \%$ in countries with higher development, however, in countries with lower development the prevalence of anaemia is 
43\%" (Balajaran et al, 2011, pg. 2123). The fact that anaemia affects particular regions disproportionately to other regions, suggests that anaemia is a health condition that contributes to worldwide health inequalities. In addition, data from the World Health Organization speak to anaemia being a condition that doesn't get enough attention despite the fact that it affects millions of people, particularly children and pregnant women. This observable lack of global emphasis sparked the majority of my research, particularly centered upon the rates of IDA among women of reproductive ages in developing countries.

\section{RECURRENT FORMS OF INTERVENTION}

There are two main forms of intervention to prevent and treat IDA: iron supplementation (i.e. iron pills) and iron fortification (i.e. iron fortified foods). The assumption that the provision of iron pills or iron droplets to treat and prevent anaemia is not wrong but it is overestimated, since the burden of IDA is still a prevalent health issue around the globe.

\section{A) SUPPLEMENTATION}

Supplementation is the primary form of intervention to combat anaemia. However, its intended effect depends on the compliance of the patients which is usually obstructed by the side effects of iron pills. It is also argued that "women do not receive proper instruction about the importance of taking iron tablets regularly and they also do not obtain adequate follow-up at their regular visits about the use of iron supplements," (Cook, 1994, pg. 224) which becomes a relevant factor in non-compliance as well.

Iron supplements are known to cause gastrointestinal side effects "in up to $50 \%$ of patients" (Breymann, 2015, pg. 591). "Nausea, epigastric discomfort, and occasional vomiting that occurs within an hour or two of taking iron pills," (Cook, 1994, pg. 225) are common 
contributors to the non-compliance of the patients. It has also been shown that "only $36 \%$ of pregnant women regularly took oral iron, even if they had been specifically informed about the problems of iron deficiency" (Breymann, 2015, pg. 591). The biggest obstacles in supplementation as a primary intervention for IDA are that women don't take the pills either because they are intimidated by the severity of the side-effects or because there is a lack of understanding about the importance of maintaining sufficient levels of iron in the body during pregnancy.

Nonetheless, iron supplements can come in many forms, and the iron polymaltose complex (IPC) is one of the few oral iron compound supplements available that belongs to the class of so-called slow-release iron preparations. The advantages of this iron supplement are "first, its favorable side-effect profile compared with iron salts as a result of the slow release, and, second, that it can be taken with meals" (Breymann, 2015, pg. 592). In other words, IPC doesn't cause the level of severe or debilitating side-effects that result from the most recurrent iron supplement, iron salts . Despite the advantage of IPC over ferrous salts (FS) - the most commonly prescribed treatment that includes ferrous sulfate, ferrous gluconate, and ferrous fumarate that work in iron formulation to increase iron and hemoglobin concentrations (Ramírez-Luzuriaga et al., 2018)—“the efficacy of IPC has not been well established in pregnancy" (Saha et. al, 2007). Studies have shown that IPC is as effective as FS, however, there are also studies that contradict these results. Additionally, most of the conducted studies that informed the efficacy of IPC have been done in non-anemic pregnant women. Further studies are necessary to strengthen and prove the efficacy of IPC. 
Despite the fact that supplementation as a prevalent form of intervention is impacted by non-compliance, this approach to treat anaemia does have the potential to play a part in the solution. In fact, if compliance is achieved, iron pills are the most effective solution for a fixed amount of time and the benefits can be seen in patients who maintain consistency in the treatment. For instance, a double-blind randomized trial was conducted where a group of pregnant women were given iron supplements and another group were given a placebo, the results showed that "supplemented women had significantly longer gestation durations $(+0.6$. wk), and increased infant birth weight $(+206 \mathrm{~g}$.$) than those who were not supplemented" (Scholl,$ 2005, pg. 1220S). Furthemore, those who received iron supplements also saw reductions in preterm delivery, but this finding was not considered significant due to the trial participants being in their second trimester of pregnancy.

\section{B) FORTIFICATION}

Food fortification is generally considered "the most cost-effective method for providing additional iron for populations with a high prevalence of nutritional iron-deficiency" (Lynch, 2011,pg.765S). However, this vehicle to combat anaemia might not reach people that have restricted access to processed foods. The success of iron fortification depends on the "bioavailability of the iron compound employed, the inhibitory and enhancing effects of absorption of the meals in which it is eaten, the level of addition, and the consumption pattern of the vehicle to which it is added" (Lynch, 2005, pg.338). Therefore, if an individual's diet contains iron inhibitors and they are only exposed to minimal iron-fortified foods, the effect of increasing their iron levels will not be as significant or meaningful. 
Additionally, food fortification is one of the principal factors that results in an observable difference between developed and developing nations' furthered by the prevalence of iron deficiency. To illustrate, the fortification of wheat and bakery products was first introduced in industrialized countries during World War II, and currently provides "between $10 \%$ and $40 \%$ of the dietary iron intake" (Cook, 1994, pg. 225) to their populations. Moreover, "wheat flour has been fortified with iron in Canada and the United States since the 1940s,” (Lynch, 2011, pg.763S) which marked a stark decline in the prevalence of IDA in these countries. There was also a decline in IDA prevalence in infants and young children, attributed in part to the fortification of infant formula and weaning foods.

Three categories of fortification were defined by the WHO/FAO: (1) market-driven fortification of products such as breakfast cereals and other staples that the population tends to eat regularly; this type of food-fortification has been implemented in many industrialized societies. (2) Targeted fortification, which is designed to meet the needs of specific groups, such as fortifying formula-feeding for children and infants. (3) Mass fortification, defined as the addition of micronutrients to food, and generally in the food staples consumed in greater amounts by the public.

On one hand, it could be argued that the prevalence of IDA is an easy problem to fix by mass fortification, however, this method has its concerns due to the health risks associated with over-supplementation of iron in the diet; "particularly the risk of iron overload among men if mass fortification is introduced" (Lynch, 2011,pg.765S). Furthermore, it cannot be assumed that fortified-food staples would be accessible across cultures, because in the implementation of an effective food-fortification method "cost becomes very important in selecting the best approach 
to implementation" (Hurrell et. al, 2004, pg. 398). Accessibility becomes an issue because iron-fortified foods would not be as affordable even at reduced prices if government subsidies are challenging to obtain.

Despite these two types of recurrent interventions, personal behaviors, scientific studies, and economic bioavailability play an important role in better assessing the social conditions of anemia and the provision of quality iron pills to improve patient compliance. A multidisciplinary perspective when diagnosing IDA is suggested as the result of such narrowed forms of intervention and prevention.

From the library of research and studies performed, I question: Why is a patients' lack of compliance with taking iron supplements still an obstacle, despite the worldwide narrative of IDA and its major effects on the cognitive development of children? Are the secondary effects of iron pills the only factor for non-compliance? And why is the burden of IDA as a prevalent public health issue centered in developing regions?

\section{Framework}

The previous exploration into the background of the discourse serves as the basis to frame my research question_-Why is iron-deficiency anaemia still a public health issue for developing countries, despite the advancements of medical diagnosis and availability of iron supplements? — which I will attempt to answer by introducing literature about iron-deficiency anaemia, explicitly concentrated on studies about developing countries. In addition, to exemplify the current practices of developing countries, I designed and performed a case study in two governmental public hospitals in Lima, Peru that I will review and discuss. 
The literature reviewed focuses on previous and current cohort and randomized studies attempting to prove the efficiency of iron supplements. For the most part the article by Cook (1994) sets up the framework and discusses the stages of iron-deficiency anaemia worldwide before the 2000's, shedding light on the health inequity between developed and developing regions. The bulk of the research articles that frame the overall current understanding of and identifies forms of interventions for iron deficiency anaemia, as well as options for enhancing iron-fortified foods, are dated from the 2000s. However, it is around 2010 when researchers started asking themselves why anaemia is still an issue when centered in the developing world, despite all the trials done in order to understand how iron is better absorbed in the human body.

The current literature of iron-deficiency anaemia dating from 2015 onward tries to incorporate a "multidisciplinary perspective" to study this public health issue, through the additional lens of the social determinants of health in which socioeconomic status, diet, access to health services, and access to education play important roles in determining the current stage of anaemia in many developing countries. Such is the case of Lima, Peru, which incorporated the 2018 nationwide campaign \#luchacontralaanaemia. The focus of this campaign wasn't only to increase hemoglobin levels for pregnant women and children, but centered a more holistic approach based on prevention that involves many other public health practitioners and local governments.

With the recollection that the groups at most risk of developing IDA are children and women of reproductive age. For the purpose of this project, I focus on examples of women of reproductive age, with a particular take on the experiences of pregnant women. With the mere purpose that pregnant women's health also influences the health of the baby, and in focusing on 
pregnant women, I gain further data on elements that determine the health status of the child. I will draw examples from current diets, health practices in IDA diagnosis, but most importantly, I will try to understand how growing misconceptions and the lack of cultural/public understanding of anaemia informs the non-compliance factor previously discussed.

The literature review will be analyzed under the umbrella of the social determinants of health, since much of the work that iron-deficiency anaemia research misses is concentrated in areas that can be improved by applying a multidisciplinary perspective.

\section{Literature Review}

The focus of the literature review will be based on "the case of developing countries" where the prevalence of anaemia concentrates in regions like Africa, South-East Asia, and East Mediterranean, with less incidence in Europe and the Americas. (Under the umbrella of 'The Americas' the territories encompassed include the United States and Canada, as well as the countries of South America. This coupling works to distort the data from South American countries that experience a disproportionate number of cases compared to North American territories). However, based on the "social gradient" of health (see Box 1.), we can make the assumption that within each region there is a social gradient of health based on socioeconomic status in which populations located at the bottom of the ladder experience health hardships in greater amounts.

\section{Box 1. Social Determinants of Health \& Social Gradient of Health}

The social determinants of health are the conditions in which a person "is born, grows, lives, work and age". These circumstances are constantly shaped by the distribution of "money, power, and resources at a global, national, and local level" (WHO, 2020). Marmot and Allen argued (2014) that the magnitude of health inequalities is an indicator of the impact of social 
and economic inequalities on people's lives (pg. S517), and therefore, the unfairness and differences in health status that we see within and between countries are attributed to the social determinants of health.

In addition, one of the particular issues that stand in the way of addressing the social determinants to finally achieve health equity is the so-called lifestyle drift, "which describes the tendency in public health to focus on individual behaviors, such as smoking, diet, alcohol, and drugs, that doubted causes health inequities" but we fail to ignore the drivers of these behaviors “[...]the causes of the causes" (Marmot \& Allen, 2014, pg. S517). In this sense, the use of the social determinants of health as a lens will certainly improve the understanding of our surroundings which will then point us towards integrated strategies to reduce health inequities and improve health status overall.

Nonetheless, health inequalities are not limited to "only poor health for the worst off, or the most socially disadvantaged. There is a striking social gradient in health and disease running from top to bottom of society" (Marmot \& Allen, 2014, pg. S518). The social gradient of health is a term utilized to describe the phenomenon of worse health attributed to those at the bottom of the socioeconomic ladder than those who are at a more advantage and higher position in the ladder. However, the bottom of the socioeconomic ladder in a developed country might not indicate the same disadvantage for the bottom of the socioeconomic ladder in a developing country.

According to Millman (2011), in both developing and developed countries the prevalence of anaemia has a social imbalance, meaning that there is a higher prevalence in the lower social strata of the low-income groups, which is also the case among the least educated portion of the population. Anaemia is then understood as "a marker of socioeconomic disadvantage" with the poorest being at a greater risk of exposure to risk factors of anaemia and its consequences (Balajaran et, al, 2011). 
Utilizing both the social determinants of health and the social gradient of health as a lens allowed me to frame the case of developing countries as an issue in which wealth equals access to health.

\section{THE CASE OF DEVELOPING COUNTRIES}

The causes of anaemia in countries with low or middle income are concentrated in three different areas:
"Nutrition (iron deficiency, folic acid deficiency, vitamin B12 deficiency, Vitamin A deficiency, and protein energy malnutrition), Genetic hemoglobin disorders (thalassaemias, hemoglobin variants, etc.), and Infectious Diseases (soil transmitted helminths, malaria, Schistosomiasis, tuberculosis, AIDS, tropical sprue, malabsorption and disorders of the small intestine)"

(Balajaran et al., 2011).

The areas described above as factors that cause anaemia can be interpreted as:

1. Diet behaviors (heme vs. non-heme iron foods, iron inhibitors)

2. Health Practices/diagnosis of IDA (misdiagnosis of genetic hemoglobin disorders leading to iron overdoses).

3. Presence of infectious diseases that maximizes the onset of anaemia.

However, with careful consideration researchers have agreed that these three areas are not the only factors that cause iron-deficiency anaemia. Therefore, using the lens of the social determinants of health, three other areas have been aggregated in order to fully understand the 
phenomenon of iron-deficiency anaemia among women of reproductive age in developing countries:

4. Pregnancy and parity (frequency of births shows differences in iron stores) effects among nulliparous, uniparous, and multiparous women, as well as, the challenges faced by early onset of childbearing and short intervals between births.

5. Biological developmental (adolescence) where iron is needed in greater amounts than the normal dose, due either to unavoidable growth spurts or menstruation cycles.

6. Misperceptions of anaemia (wrong understanding of anaemia that leads to non-compliance with iron supplements).

The following paragraphs will discuss almost every factor that contributes to the inception of iron-deficiency anaemia. I will bring in examples from epidemiological research articles presenting an overview of current practices used to diagnose anaemia, and nuanced research conveying factors that are not usually discussed in the literature of iron-deficiency anaemia. Correspondingly, the factor "Infectious Diseases" will not be discussed in detail since it will mean broadening the focus of the paper by inviting the reader into a discussion that involves other areas of study. Needless to say, infectious diseases are an important factor to take into consideration when diagnosing for IDA, since the prevalence of IDA in a particular region can be deepened with the presence of infectious disease.

\section{a) NUTRITION}

The bioavailability of iron or dietary iron consists of two categories: "heme and nonheme iron". Heme iron is from animal origin, and is classified as having higher bioavailability since it leads to favorable gastrointestinal iron absorption. Meat also contains what is called the "meat 
factor" which enhances the absorption of nonheme iron, iron found on plants (Millman, 2011, pg. 370). Nonheme iron on the other hand, is classified as having lower bioavailability indicating low iron absorption. However, when accompanied by vitamin $\mathrm{C}$ or ascorbic acid, iron absorption from nonheme iron is increased, but not to the extent of being able to replace the consumption of heme iron.

Human diets have shifted over time from hunter-gatherer to more cultivated cereal-based diets. Furthermore, heat exposure has increased when preparing food. Due to these latest eating behaviors, there has been "a large drop in bioavailable haemopoietic nutrients (iron, vitamin B12, and folic acid) and absorption enhancers like vitamin C," indirectly contributing to the development of iron deficiency, and in the long run to IDA (Balajarian et al., 2011, pg. 2127). Additionally, developing countries' diet is composed mainly of foods of plant origin (nonheme iron), foods of low iron content usually eaten together with a diet rich in cereal grains, which are “strong inhibitors for iron absorption" (Millman, 2011,pg.373). Furthermore, the widespread consumption of coffee and tea in some other regions contributes to an impairment of iron absorption from some foods.

A research study done in rural Honduras by Ohri-vachaspati \& Swindale (1999) among women and children and the iron in their diets suggested that the main cause of iron deficiency anaemia in developing countries was the poor availability of absorbable iron from their diets. For instance, Honduras' corn-based diet shows a higher intake of "phytates" in the form of corn, wheat, sorghum etc. — known to be iron inhibitors-, paired with a low intake of fruits and vegetables - primary sources of ascorbic acid-, together with foods of animal origin — consumed in very small amounts_-, and finally, the ingestion of coffee and tea by all age 
groups further limits the availability of dietary iron since "each cup of tea or coffee consumed with the meal can reduce the availability by $20 \%$ to a maximum of $60 \%$ " (Ohri-vachaspati \& Swindale,1999, pg. 289). The research concluded that after computing the role of inhibitors and enhancers in the Honduran diet "less than $5 \%$ of dietary iron was available for absorption," (Ohri-vachaspati \& Swindale,1999, pg. 295) due to a poor quality diet and high levels of coffee ingestion.

A cross-sectional research study conducted by Samuel et al. (2013) with pregnant women of urban South India correlates anaemia with their dietary habits, and argues that there is in fact an identified prevalence and there are dietary correlates of anaemia as early as the first trimester of pregnancy. Studies conducted in India suggest that "micronutrient deficiencies (Fe [iron], folate and vitamin B12) are the primary cause of anaemia in pregnancy" (Samuel et al., 2013, pg. 316) with less association of maternal age, parity, income and education. It was concluded that the Indian diet is high in energy content but poor in quality. To illustrate, pregnant women consume high amounts of Vitamin $\mathrm{C}$ related foods but the "prolonged cooking and storage of food can reduce its enhancing effect". In addition "higher intake of $\mathrm{Mn}[$ magnesium] may impose a risk for reduced Fe[iron] utilization by affecting Fe absorption, while higher doses of Zn[zinc] in aqueous solutions are known to impair Fe absorption" (Samuel et al., 2013, pg. 321). Likewise, a higher intake of calcium was associated with risk of developing anaemia, and a higher intake of phosphorus was observed to be "an independent risk factor" (Samuel et al., 2013, pg. 322) for anaemia among pregnant women. 
Repeatedly, it is emphasized that a poor quality diet, higher intake of food-iron inhibitors, low bioavailability of iron in the diet, and high intakes of calcium and phosphorus are a recipe for a higher risk of developing iron-deficiency anaemia.

\section{b) HEALTH PRACTICES / DIAGNOSIS}

In many impoverished settings in which "access to routine biochemical and haematological testing is scarce, diagnosis relies on history and clinical examination alone" (Balajaran et al., 2011,pg. 2125). However, accurate diagnosis can be difficult, especially if a patient is misdiagnosed with a genetic disorder, such as thalassemia. IDA and thalassemia are both conditions that affect pregnancy, but both have to be treated very differently because "thalassemia mutations can lead to iron overload in the host by mechanisms that are not fully understood" (Miller, 2013, pg. 9). Therefore, if an individual is diagnosed with IDA but in reality has thalassemia, then the ingestion of iron supplements work against the treatment, resulting in an overload of iron in the body that can lead to death. What's more, iron overdose is shown to “build up the mother's iron store and increase blood viscosity so that utero-placental blood flow is imparied or that the excess iron intake could cause other toxic reactions" (Scholl, 2005, pg. 1220S). In addition, high levels of iron are also related to increased risk for "the development of gestational diabetes mellitus (GDM) among pregnant women" (pg. 1221S). It is important to highlight that in many tropical and subtropical countries the high prevalence of genetic hemoglobinopathies (thalassemia, sickle cell disorders, etc.) play a significant role in the prevalence of anaemia (Millman, 2011). In these regions the prescription of iron pills to treat genetic disorders and diseases should be more carefully diagnosed. 
As an illustration, a recent cross-sectional research study carried out among pregnant women from the rural areas of Indonesia by Susanti et al. (2017) tried to explore whether anaemia among Indonesian pregnant women was due to an IDA or thalassemia trait. Through an administered finger prick test (recurrent form of measuring $\mathrm{Hb}$ levels) it was estimated that a large proportion had developed IDA, however, when a more accurate test was administered, "a significant difference in frequency of anaemia in pregnant women using finger prick test and CBC, that is, $86.7 \%$ and $21.9 \%$, respectively" was found (Susanti et al., 2017, pg. 3). Through these results, it was determined that the majority of individuals who tested for IDA actually suffered from thalassemia. It is argued that in areas with limited resources, anaemia during pregnancy is often examined by low-cost tests where inconsistencies "seem too high and may lead to overprescription of iron supplementation" (Susanti et al., 2017, pg. 3). The lack of technology to accurately diagnose thalassemia from IDA is a major concern that leads to iron over-supplementation.

On a different note, there are some health practices that help the mother prevent the early onset of IDA on their newborn. Miller (2013) argues that delayed clamping of the umbilical cord helps prevent iron deficiency among newborns, suggesting that a delay of 5 minutes "results in $166 \mathrm{~mL}$ of added blood volume for a $3.5 \mathrm{~kg}$ infant” (Miller, 2013, pg. 8). Additionally, the study suggested that infants who had undergone delayed clamping had higher ferritin levels than their counterparts, who experienced a "decrease in ferritin levels of 7.4\%" almost immediately after delivery (Miller, 2013,pg. 9). One could easily think that a cesarean delivery (CD) might play a role in reducing placental transfusion and cause poor iron-related outcomes in the neonate, but a study done by Wilunda et al. (2018) did not observe any association between CD and any degree 
of anaemia among children aged less than 5 years in LMICs; early childhood anaemia was attributed to a lack of intervention controls such as iron supplementation, exclusive breastfeeding, and adequate nutrition.

\section{c) PREGNANCY AND PARITY}

Anaemia during pregnancy is noted to have negative maternal and health effects which increases the risk of maternal and neonatal mortality, specifically contributing to " $23 \%$ of indirect causes of maternal deaths in developing countries" (Stephen et al., 2018, pg. 2). Likewise, anaemia during pregnancy correlates with an increased risk of the following health concerns: preterm birth, low-birth weight (LBW), intrauterine deaths (IUFD), low APGAR scores at 5 minutes - a scoring system to assess newborns where lower scores indicate the baby needs special care - and intrauterine growth restriction (IUGR) that poses a risk to the developmental growth of children. In addition, the ideal amount of iron storage at birth is unknown, but data suggests that the "developing fetal brain is susceptible to iron insufficiency in utero," and low iron stores at birth are associated with infants' motor-cognitive deficits (Ru et al., 2016, pg. 1052). Furthermore, current studies propose that a higher frequency of births requires greater iron storage to prevent anaemia, suggesting that nulliparous and multiparous women are at a greater risk for developing anaemia.

A study done by Stephen et al. (2018) in Northern Tanzania, assessing the prevalence and risk factors of anaemia in pregnancy, highlighted low education attainment and low attendance of antenatal care work as isolating factors for anaemia during pregnancy. The "women who attended ANC (antenatal care) 4 or more times had lower prevalence of anaemia (17.4\%) than those who attended only once (35.5\%)" (Stephen et al., 2018, pg. 6). Results were attributed to 
pregnant women's educational level. Women with primary and secondary education had significantly less odds of having anaemia due to their "higher frequency of exclusive breastfeeding, attending for antenatal care visits for 4 or more recommended visits, utilization of skilled attendance during delivery, and health care seeking when the children have pneumonia" (Stephen et al., 2018, pg. 7).

A similar cross-sectional study done in Malaysia by Hassan et al. (2005) among Malay women attending an antenatal clinic proposed that "it is important to detect iron deficiency during the first antenatal check up, as it is one of the earliest manifestations of iron deficiency". The article discovered that during the first and second trimesters "hemoglobin and hematocrit decrease as the maternal blood volume expanded" (Hassan et al., 2005, pg. 1304), meaning that if the pregnancy progressed, iron stores will be depleted even further. Screening for iron deficiency during the first antenatal visit is recommended, since iron deficiency is still the leading cause of nutritional deficiency among pregnant women. However, in the previous study, not every pregnant woman made it to their first visit during the first trimester, due to a lack of health resources and education attainment.

On another note, iron deficiency and anaemia are highly prevalent in women with multiple gestations, but little attention has been placed on the particular iron demands of multiparous women. Ru et al. (2016) conducted a cohort study of healthy women with multiple gestations and measured for prevalence of iron deficiency and anaemia. The article stated that "very little is known about iron status in women with multiple gestations." Besides, "it is unknown if the typical iron content of a standard prenatal supplement $(27 \mathrm{mg})$ is sufficient for all higher-risk obstetric groups" (Ru et al., 2016, pg. 1052). Results indicated that anaemia rates 
were "4-fold higher than the expected national prevalence reported for women who were carrying singletons" (Ru et al., 2016, pg. 1058). An early screening for maternal iron status for this high-risk group is recommended to assure that since the first intervention iron-supplementation can quickly be initiated if needed.

\section{d) BIOLOGICAL DEVELOPMENT}

The biological development that women of reproductive age experience leads their bodies to be in greater need of iron. Mengistu et al. (2019) argue that even though IDA is the most common cause of anaemia, other conditions such as nutritional deficiency, chronic inflammation, parasitic infections, genetic disorders, growth spurts, and increased iron loss from the body during menstruation are also factors that can lead to anaemia if not watched closely. The high iron needs in girls of childbearing age is caused by an "increased requirement for expansion of blood volume associated with the adolescent growth spurt and the onset of menstruation" (Akramipour et al., 2008, pg 354), and it is estimated that iron requirements increase "two- to threefolds during adolescence due to high growth spurt and the loss of 12.5 - 15 mg iron each month" (Mengistu et al., 2019, pg. 2). In addition, the occurrence of pregnancy among adolescents with anaemia increases the chances for "maternal morbidity but also the incidence of poor maternal birth outcomes such as stillbirth, low birth weight, and prematurity" (Mengistu et al., 2019, pg. 2) impacting the infant's iron status. Several studies conducted to assess iron levels among adolescent girls tended to omit the adolescent's living conditions, knowledge of anaemia prevention, and availability and consumption of foods rich in iron.

To illustrate, Akramipour et al. (2008) conducted a cross-sectional study among adolescent schoolgirls from Western Iran to find out the prevalence of iron-deficiency, iron 
deficiency anaemia, and anaemia. Factors like diet, parasitic infections, sanitary conditions, or knowledge of anaemia were not taken into consideration, which pointed out an absence of a "significant difference between the presence of anaemia and the level of education of parents." Nonetheless, "a prevalence of 39\% for ID among 15-49 years-old women in Iran was indicated by national reports on anaemia in Iran" (Akramipour et al., 2008, pg. 353). In light of that, a prevention program was recommended to establish higher priority on the health systems of the country, coupled with this, a weekly iron supplementation was recommended.

Mengistu et al. (2019) conducted a more recent cross-sectional study in North West Ethiopia on 443 randomly selected school adolescent girls, to assess the prevalence of anaemia while considering the associated factors of anaemia for adolescent girls. The predictors of anaemia (third variables) considered in the study were the following: household monthly income, family size, intestinal parasite infections, duration of menstruation, and BMI. Results showed that "more than three fourths, $332(78.5 \%)$, of the participants had not heard about anaemia", with more than half of the respondents saying that "they drink tea immediately after a meal within 30 minutes", and almost all of them “419 (99\%) did not have a history of iron supplementation” (Mengistu et al., 2019, pg. 3). Moreover, large family sizes meant lower income that lead to less variety of food rich in iron content, and therefore, adolescent girls who had a household family size greater than five were "3.2 times more likely to be anemic" compared to those who had household family sizes less or equal to five (Mengistu et al., 2019, pg. 5). Furthermore, adolescent girls who experienced menstrual flow of more or equal to five days per each cycle "were 2.4 times more likely to develop anaemia" compared to those who experienced it less than 5 days (Mengistu et al., 2019, pg. 4). The study concluded that the 
intervention should focus on prevention and early treatment of intestinal parasites, nutritional education, screening, and iron supplementation programs.

\section{e) ANAEMIA PERCEPTIONS}

The view of anaemia "as a non-urgent maternal health problem compared to other serious illnesses" (Compaore et al., 2014, pg. 1977) is of great importance when introducing an intervention plan. The patient's lack of concern is reflected in the limited understanding of anaemia and the role of iron in the body. Studies of women in both developing and developed countries have shown that "women held a variety of concepts about anaemia and its treatment, including folk beliefs and biomedicine" (Ailinger et al., 2009, pg. 149), which are fueled by the absence of studies discussing "the detailed content of the educational messages used to describe anaemia" (Compaore et al., 2014, pg. 1981). As a matter of fact, "concepts of disease are influenced by education, economics and most importantly by culture" (Ailinger et al., 2009, pg. 148), and therefore a difference between patient and health providers' perspectives leads to misunderstandings and problems of non-adherence to prescribed treatments. In addition, Galloway et al. (2002) provided reasons for ineffective programs beyond the compliance of iron tablets, such as: inadequate supply, poor quality tablets, issues with delivery and distribution, poorly trained health providers, ineffective communication of materials to promote behavior change, lack of access to prenatal care, and very poor monitoring of the problem. In fact, women's perceptions of anaemia tend to go unnoticed, when in reality they should be central to any discussion trying to approach iron deficiency anaemia.

Commonly cited is an article by Galloway et al. (2002), which shares women's perceptions of iron deficiency and anaemia in eight developing countries. Qualitative research 
under The MotherCare Project was conducted to determine the major barriers and facilitators of iron supplementation programs for pregnant women. Multiple barriers were identified during the study, one of them being in South India and Malawi, where iron supplements were understood to increase blood, and therefore, some women believed that "they will bleed more profusely during delivery if they consume iron during pregnancy" (Galloway et al., 2002, pg. 539). In another instance, although women of India recognized anaemia as a serious issue that could require blood transfusion, weakness and fatigue — indicators of anaemia—were considered to be normal during pregnancy, where the majority didn't seek treatment unless it was severe. Additionally, iron tablets were presumed to cure anaemia "but not to prevent the condition" (Galloway et al., 2002, pg. 540); hence, Bolivian women who attend prenatal care were familiar with iron supplements but few of them believe that it would alleviate anaemia symptoms. Alike, taking iron pills during pregnancy for Honduran women was associated with "cavities or spots on babies' teeth and face spots on mothers;" moreover, women from Bolivia and Honduras were “concerned that taking 'medicine' during pregnancy could harm their unborn baby" (Galloway et al., 2002, pg. 540, 542). Nonetheless, distribution and adequate supply of iron supplements were the major barriers; for instance, women in Latin American countries were reluctant to accept supplements outside of the government health system, compared to women in South India who were suspicious of the quality of government-supplied pharmaceuticals, and in Malawi, where only the women diagnosed with anaemia were eligible to receive iron tablets.

The cultural beliefs identified in the previous article are not the only barriers for iron consumption. A qualitative study design by Ailinger et al. (2009) aimed to examine the concepts of anaemia in low-income Nicaraguan women. The findings indicated that few women had 
biomedically accurate concepts of anaemia, due to the lack of iron from poor eating, while others held folk medical beliefs_- home remedies_-and appealed to certain diets to cure anaemia. When the women were asked how anaemia develops, "they responded with the themes of poor eating and lack of vitamins." However, none of them could "differentiate the various types of anaemia" (Ailinger et al., 2009, pg. 150). Home remedies consisted of habits of eating certain foods like bean soup — which was made from soaked beans and boiled in the same water which they were soaked - a cooking method that might lead to the opposite effect of absorbing iron from beans since the "soaking process allows for tannins found in the skin of the beans to be released in the soaking water". It was concluded that "identified cultural beliefs" (Ailinger et al., 2009, pg. 151) should be a factor to take into consideration when interacting with women from different cultures, and especially when wanting to mitigate the onset of a nutritional anaemia due to certain diet practices.

A more recent study by Compaore et al. (2014) on Burkinabe women's perceptions of iron supplementation communicated that anaemia was described in terms of blood volume: moderate blood loss or "diminished blood" was understood to be easily replaced by eating well was not considered serious, versus massive blood loss or "finished blood" which was rare but understood as a life-threatening illness. The participants described blood as "the key to good health" since blood prevented sickness from overwhelming you (Compaore et al., 2014, pg. 1980). Accordingly, losing blood was associated with weakness and loss of power. Surprisingly enough, however, menstruation was excluded from such interpretation, and instead was interpreted as a normal activity that couldn't cause anaemia. The same logic applied to short-lived infections, which were treated as a minor cause of blood loss or diminished blood, 
and therefore never escalated to a major concern. Women had no knowledge of iron's role in the body and "it became clear that women used the term iron symbolically", making it difficult for them to conceive that iron supplements actually contained iron, and concern that taking iron could perforate the intestines (Compaore et al., 2014, pg. 1980). The study concluded that better clarity for "why even a small lack of iron can have detrimental effects" (Compaore et al., 2014, pg. 1982) should be addressed before it becomes a life-threatening issue. Furthermore, a concrete and understandable explanation of iron's role in the body is necessary when trying to move away from inaccurate perceptions of anaemia and its consequences.

\section{Case Study}

The following qualitative case study hopes to bring health professionals' perceptions and perspectives of iron-deficiency anaemia among the population that they served. Thirteen midwives were interviewed during their shifts, and in some particular occasions in between patient appointments. The interviews took place in first-and-second tier hospitals in Lima, Peru of low-income neighborhoods. First-tier hospitals refer to antenatal care places where the component of education and prevention of health is greatly emphasized; these are centers where the majority of pregnant women come for their check-ups, and in lower incidence they bring their children for health check-ups. Second-tier hospitals on the other hand, concentrate their services on more complicated procedures, related to assisting the births, and less emphasis is given to health consults or one-on-one sessions with a health professional. The purpose of carrying interviews among health professionals from a developing country will inform my thesis of a perceived general awareness of IDA among disadvantaged populations, and highlight the most immediate obstacles that enforces the onset of anaemia among pregnant women, and 
consequently, their children. Lastly, Peru's multisectorial plan to defeat anaemia will be discussed, and midwives' impressions will be shared.

\section{ANAEMIA IN PERU}

In Peru, anaemia is a severe public health problem that affects around $43.5 \%$ of the population, mostly concentrated among children under 5 years of age (Quezada et al., 2018). As for pregnant women it is recorded to affect 29\% (Ministerio de De sarrollo e Inclusión Social, 2018). The principal causes for anaemia in Peru are lower iron intake and poor bioavailability, since the majority of diets include non-heme iron and they are usually eaten with grains, coffee, or tea-iron inhibitors. Another principal cause of anaemia is the high presence of infectious diseases, concentrated among newborns and children under 3 years of age. Comparatively, only $27 \%$ of peruvian households have access to clean water (INEI, 2017).

Another factor that contributes to the onset of anaemia in the Peruvian population is the high incidence of pregnancies among adolescent girls. Between the years 2016 and 2017 an augmentation from $12.7 \%$ to $14.4 \%$ was recorded at a national level of adolescents girls between ages 15 and 17 who had been pregnant at least once (Ministerio de Desarrollo e Inclusión Social, 2018, pg. 38). Adolescent pregnancies lead to birth complications and lower birth weight among newborns, and in Peru 22.8\% of newborns are preterm delivery, and 7.3\% of newborns are born with low-birth weight (INEI, 2018).

One of the major obstacles to combat anaemia in Peru is the lack of understanding of the role of iron in the body, which then drives the non-compliance of pregnant women taking iron supplements, and further imposes obstacles to new measures taken by the Ministry of Health. Such was the case of 2013, where the State of Peru attempted to implement change by offering 
powdered micronutrients, which contained iron, folic acid, sinc, and vitamins $\mathrm{A}$ and $\mathrm{C}$; however, $70 \%$ of children under 36 months did not consume this form of iron. In other words, only three out of ten children under 3 years of age were consuming iron (Ministerio de Desarrollo e Inclusión Social, 2018). Further driving the curve of anaemia among children.

\section{Methods: Case Study}

Thirteen midwives were interviewed. Two midwives from "postas medicas” (“antenatal care") in reference to first-tier hospitals. The first interview took place in Chacarilla's urbanization, and the second interview in San Fernando's urbanization. Both districts are considered to be low-income and the "postas medicas" are the primary healthcare source for the majority of the population of the zone. First tier hospitals are not large in size, but they are diverse in the resources they offer. For our purposes we only focused on the role of the midwife as the main consultant for pregnant women. Both midwives were interviewed during their shifts, since it was almost impossible to find another time to meet them outside of work.

The other eleven interviews took place in "San Juan de Lurigancho's Hospital”, a second-tier hospital in the urbanization of Canto Grande. Second-tier hospitals concentrate their services on medical and surgical procedures. Even though their focus doesn't rely much on health education, they still get the majority of the influx of patients. Midwives in this hospital setting were even more busy going in and out of the surgical room. Therefore, our interviews took place in between short breaks, and some of them during vigilance of pregnant women about to give birth. It is important to recognize that all the interviews were carried out at healthcare centers located in the district of San Juan de Lurigancho, which is considered one of the most populated, and poorest, districts of Lima. 
All the midwives anonymously interviewed were administered the same set of eight questions (appendix B), which covered the following themes: incidence of patients with anaemia, differences of anaemia between rural and urban population, awareness and understanding of iron supplements during pregnancy, principal causes of anaemia of pregnant women, incidence of adolescent pregnancies and its complications, secondary effects of iron supplements and patient instructions, health practices to lower the risk of anaemia in newborns such as delayed clamping of the umbilical cord and its practice, and awareness of the multisectorial plan against anaemia lead by the federal government. All of these questions were asked and responded to within a window of 10 to 15 minutes per interview. All of the interviews were conducted in Spanish and translated into English by the researcher.

Limitations and Privileges: Originally, the project was to interview both health professionals and pregnant women, in order to get both perspectives and compare them. However, due to technical limitations I was only able to interview health professionals —midwives. The opportunity to interview midwives was possible due to my mother's line of work. Thanks to her being a midwife, I had the privilege to interview her colleagues. Otherwise, I would have not been able to get any interviews due to the lack of trust of outsiders of the community who want to research this particular population.

\section{Results: Case Study}

The thirteen midwives agreed to be interviewed in between and during their shifts. All of the eight questions asked were responded to partially or fully depending on the interviewee's knowledge and time given to the interview. No one dropped or partially stopped the interview, and the majority answered the questions from their personal experiences. Rough estimates of the 
incidence of anemia were provided, and answers to some of the questions agreed with other responders; however, different opinions for the principal causes of anaemia and the lack of compliance of iron supplements were recorded.

The following is a compilation of the midwives' answers for each of the questions asked during the interview(s): Incidence of anaemia. It was clear during the majority of the interviews that the incidence of anaemia was more prevalent among children than women of reproductive age. The fact that the interviews were carried out in a low-socioeconomic district, the majority of the answers pointed out the inaccessibility to foods rich in iron content, and that the majority of families ate processed food, or whatever was affordable ("Al alcance de su bolsillo").

Furthermore, due to the high incidence of adolescent pregnancies, complications during the birth are not uncommon. A couple of the midwives argued that pregnant women come already with bad eating practices, and besides having arrived at the hospital with low hemoglobin, bleeding during birth also gets out of control ("Viene con mala alimentación, y a parte de ingresar con una hemoglobina baja, el sangrado se complica"). A greater number of midwives articulated that pregnant women come to their first check up, sometimes having already developed severe anaemia, and there have been some patients that have arrived with 4g/dL ("Han habido pacientes que han llegado hasta con cuatro de hemoglobina"). Overall, the incidence of anaemia was understood to be an issue that pregnant women arrived with to the hospitals, or to their first check ups, and sometimes even when they were about to give birth. Due to the current issues, the sentiment among midwives is that correcting anaemia in pregnant women near childbirth is a hopeless task. 
Iron Pills. The majority of the answers revolved around two ideas; first they saved the iron pills ("Lo tienen guardado"), and second, they received the iron pills but they didn't take them ("Lo reciben, pero no lo toman"). The biggest issue with iron pills were the side effects, most commonly nausea for the most part, which lead to non-compliance. Midwives learn during check ups that pregnant women weren't taking the iron pills ("Cuando vienen al mes, uno recién se entera que no está tomando"). In other cases, midwives expressed their astonishment when it was time for the pregnant women to take the next dose of iron pills, and they replied that they still had them from the past month ("A otras les toca llevarse su suplemento, y ellas responden no todavía tengo del mes pasado"). The issue of non-compliance was associated with education levels. It was argued that even though midwives could explain how important it was to take iron supplements during pregnancy, if the pregnant women were not aware of the consequences of anaemia, they wouldn't comply ("Dado al nivel educativo, por mas que tu les expliques, no lo aplican y no se concientizan"). Finally, some of the midwives attributed the non-compliance factor to the quality of iron pills that the government provides to all medical centers; moreover, it was mentioned that some of the patients might already have previous gastritis, the side effects of which could be doubled by consuming iron pills.

Prescription of Iron Pills. This theme was sparked during the conversations around iron pills, and it deserved its own section since its prescription can be an important factor in preventing the onset of anaemia. In accordance with the Ministry of Health of Peru, health workers are in charge of prescribing folic acid and ferrous sulfate to any patient at 14 weeks of pregnancy ("De acuerdo al ministerio de salud, nosotros tenemos encargado la entrega del ácido fólico a la paciente con 14 semanas de embarazo. Sulfato ferroso, también a partir de las 
14 semanas"). Despite the recommended prescription, it was highlighted that due to the amount of patients waiting to talk to a health professional consultation sessions were rushed. Therefore, the restricted time of interaction between the patient and the professional prescribing the pills wasn't sufficient to get the message across about the importance of the iron pills ("Simplemente muchas veces aquí [hospital] se les da la receta-senora tiene que tomar esta pastilla-y es algo rápido por la cantidad de pacientes que hay"). Further, there are other forms of iron that don't cause the well-known side effects. The Peruvian government, however, hasn't changed their supply to this other product. This product can be found in any pharmacy, but adding a socioeconomic lens reveals that many individuals are still unable to afford them. On a similar note, if the patient shows $8 \mathrm{~g} / \mathrm{dL}$ then an iron dextran injection must be administered. The issue is that not every patient is able to purchase the injection, therefore health workers are left to recommend drinking more water to decrease the side effects ("Ahora que sucede, no todas las pacientes te van a poder comprar una ampolla. Entonces qué hacemos. Solo le podemos recomendar que tomen más líquido").

Rural vs. Urban. Numerous scholars have highlighted the differences between rural and urban incidences of anaemia. Surprisingly, the concentration of anaemia is found in urban areas of the country, on the coast ("En la costa, en Lima es más") of the city of Lima. However, it was specified that a greater concentration occurs in marginalized zones, among individuals living in the hills where they face restricted access to basic services such as running water ("Normalmente en la zona urbana, urbana marginal, que viven en los cerritos"). The variable of higher elevation that is found in the highlands of the country was also a revised factor, since a higher elevation means higher hemoglobin levels. Therefore, an individual from the highlands that recently 
migrated to the coast, can have higher levels of hemoglobin and not be considered anaemic (“Cuando vienen de provincia suelen venir con ese tipo de hemoglobina, que allá lo que sería anaemia aca no lo es"). A different concept is applied when treating patients from the jungle. In terms of elevation there is no difference from the coast, but infectious diseases have been recorded in higher numbers in these areas. Despite their balanced diet, they are also at a greater risk ("Porque qué vale que pueden alimentar bien y todo, pero si es que tienen parásitos. Tampoco van a absorber bien los nutrientes que reciben").

Diet Practices. It was previously mentioned that anaemia in Peru was attributed to the low bioavailability of iron in the diets of many women and children. One of the reasons being that diets of individuals from the highlands are composed of potatoes, wheat, and not many foods rich in iron content (“En Puno, en Andahuaylas hay más anaemia porque solamente comen papa, trigo, no comen alimento ricos en hierro"); furthermore, midwives expressed that women from the highlands eat meat only when celebrations take place ("Carnes en dias de fiesta"), and if their chicken lays eggs, they sell them ("No comen los huevos, los venden"). The same practices can be attributed to individuals that have migrated from the rural areas to the city, who usually end up living in shanty towns or on top of the hills. On a related note, multiparous women were also at a greater risk of developing anaemia, due to the fact that quality food must be divided between so many, and therefore, nutritionally everyone gets less ("Como tienen muchos hijos, la calidad de la comida debe ser menos para cada uno, así me diga que consume hígado o sangrecita, pero está repartido entre varios, entonces te dan menos"). Moreover, one of the midwives conveyed that if food is available, the best portion goes for the father, then the kids, and lastly the mother, who is often pregnant ("La mejor presa para el papa, luego los 
hijitos, y ella es última”). Lack of information can play a role in women's diet practices; for instance, the concept of eating liver for its iron content is known, but many don't know how to prepare it. The same goes for other iron-rich foods that, if not cooked correctly, might lose some of their nutritional properties ("Por ejemplo, el hígado está ahí pero no saben cómo prepararlo. También el vaso, que se tiene que hervir, y si tu lo cocinas mucho entonces ya no tiene las mismas propiedades").

Amplifiers of anaemia. This section is dedicated to factors related to the onset of anaemia among women and children. It is a normal process for hemoglobin to drop during pregnancy, even for those who follow a diet rich in iron content and other nutrients. However, midwives point out that many women lack nutritional education and aren't aware of which foods contain iron. Additionally, iron supplements provided by the government cause secondary effects. The sum of all these factors makes anaemia a greater influence on this population. Similarly, it was highlighted that many women eat many foods that make them full, but are not necessarily nutrient dense (“Comemos bastantes comidas que nos llenan, mas no nos nutren"). Another amplifier is how soon women seek healthcare after menstruation has stopped. Midwives argued that the majority come after their first trimester, an ideal time where changes can be made to adjust hemoglobin levels ("Hay poca gente que acude en cuanto tienen la falta de la menstruación a iniciar un descarte de control prenatal. Vienen pero cuando ya pasaron el primer trimestre"). As for children, single mothers tend to leave their kids under the care of their grandparents, who are not aware of the need to give the child their multivitamins or "chispitas" (iron supplement for children). Information was recommended as one way to raise awareness among mothers, resulting in a decrease in anaemia levels among children. 
Knowledge of anaemia. Many of the sentiments among interviewed midwives revolve around the fact that women were not aware of the consequences of anaemia, and the importance of iron for the cognitive development of children. One of the midwives mentioned that they see anaemia as simply a disease, and tolerate the fact that their children have it ("Simplemente lo ven como una enfermedad, esta anemico pues, lo toleran, toleran a la anaemia"). The midwife argued that if the mothers knew, however, they would do anything in their power to bring their children to health check ups and improve their diets ("Entonces yo hago todo lo posible para llevarlo a su control del niño sano, ha hacer su chequeo de hemoglobina, a mejorar su alimentación"). An emphasis on education and information, particularly on how to eat nutritious meals, was a shared sentiment. Furthermore, one of the midwives that had experience working in both the private and public sector voiced that it was easier to communicate the important properties of iron to patients of the private sector than to the public sector ("A nivel particular no es tan dificil concientizarlos a ellos, a diferencia de concientizar a una paciente del estado, estar ahi una y otra, y otra vez").

Adolescent Pregnancy. Pregnancy among adolescent women brings many complications. Adding factors such as an inadequate diet, their families thinking it is better for them to go live with their partners, results in greater incidence of anaemia among pregnant adolescents. Midwives expressed that adolescents are the demographic that place low importance on their pregnancy, and apart from physiological changes due to their own development, their reactions are quite different from those of women who hold bachelor's degrees. ("Las adolescentes son las que muchas veces le dan menos importancia al embarazo. Entonces, a parte de muchos otros problemas psicológicos y de desarrollo que ellas tienen, no toman la debida 
importancia como una madre que haya cursado estudios universitarios”). This lack of responsibility prevents them from attending prenatal care check ups, leading to the onset of anaemia and requiring midwives to find a way to treat them ("No empiezan el control cuando uno pudiera hacerle su control prenatal y medir su hemoglobina. Empiezan tarde. Más que nada por su entorno social, y después ya nosotros nos encontramos con una mamá con anaemia”).

Health Practices. Delayed clamping of the umbilical cord is practiced in the majority of births occurring in the San Juan de Lurigancho Hospital. This practice, however, only occurs if the baby is born without any major complications. If there are major complications during the birth, midwives are instructed to cut the umbilical cord as soon as possible, then give the patient to the neonatology team ("Lo practicamos en la medida de lo posible, pero si por ejemplo, un bebé nace con falta de respiración, entonces lo cortamos rápidamente, para que el personal de neonatología se encargue"). Midwives were asked how long this practice has been around, and many of them responded within a range of three to five years. Even so, midwives expressed hope in describing that there is something they could do to help flatten the curve of the incidence of anaemia.

Multisectorial Plan. A greater portion of the interviewees disclosed that they hadn't heard about this plan, however, they did acknowledge that the government was involved. Midwives agreed that there is a bigger budget that has brought more health personnel, and that the State of Peru have finally acknowledged a need to decrease anaemia among children, thus involving the entire country ("Hay presupuesto, han contratado más enfermeras. El estado tiene que disminuir la anaemia en niños, entonces para eso hay un plan nacional. Y tienen a todo el Perú"). There have been some initiatives to fortify foods. Iron-fortified cookies, for example, 
have been developed. The Ministry of Health, however, has not approved these cookies, thus delaying the release of the cookies to the public ("El Ministerio de Salud todavia no las aprueba"). Cultural practices were recognized by some of the midwives when talking about the multisectorial plan; indeed, there are cultural differences between the three regions of the country. It is unreasonable to simply tell everyone to take ferrous sulfate ("Tu puedes decir todos tienen que tomar sulfato, y aquí es diferente que en la sierra, diferente que en la selva, y a veces eso no se puede cumplir en diferentes maneras"). Similarly, there are also instances in which women, previously having children without taking iron pills, do not understand why they should take them now ("Las costumbres que una pueda tener. Hay pacientes que ya vienen con cinco o seis hijos anteriores, y nunca han tomado esto"). 


\section{Discussion}

Iron-deficiency anaemia was sought to be treated by iron supplementation programs, yet the non-compliance factor identified in multiple studies and illustrated by the case study results, speak of a greater obstacle to overcome. As one of our interviewees pointed out, anaemia during pregnancy is the tip of the iceberg ("La anaemia en el embarazo es la punta del iceberg"). The iceberg being the underlying mechanisms of anaemia, which are better represented by genetic, economic, social and political spheres. Within the genetic sphere, it is important to understand that low hemoglobin levels during pregnancy is inevitable, but it can absolutely be treated in a way that doesn't end up in a mild or severe anemia. On a similar note, genetic hemoglobin disorders can also be the cause, and treatments are specific to each genetic health concern.

The economic sphere encompasses factors that are intrinsically related to the level of education of the target individuals; and therefore, pregnant women without the knowledge necessary to eat diets rich in iron, or understanding the benefits of taking iron supplements during their pregnancy, and further along, to bring their kids to health check ups; such individuals are still part of anaemia estimates. Similarly, economic disadvantages, greater in developing countries, dictate the availability of up-to-date equipment to accurately diagnose IDA, or time-restricted health consults provided by health workers to the uninstructed public.

The social sphere is better exemplified by personal choices and behaviors, which are in part influenced by the extent and accuracy of the information target individuals are aware of. Nutritional deficiencies established due to diet practices can be detrimental for iron stores, and even though we can argue that iron bioavailability is controversial, being aware of iron inhibitors and enhancers is crucially significant as well. Equivalently, misperceptions of anaemia and the 
erroneous awareness of iron in the body can drive many individuals to stop taking iron pills, or think that their ingestion might cause significant negative effects on their pregnancy, which is not necessarily the case.

It is within the political sphere that many aforementioned factors of anaemia arrive at a practical starting point. It is well-known that the responsibility for the health of citizens is for the most part relegated to the federal government. Access and quality of resources are at stake, and neither can decrease the incidence of anaemia alone. To illustrate, midwives in the case study discredited the quality of iron pills provided by the government, since their side-effects drove pregnant women to stop taking them. In the following paragraphs we will look at examples of fortification and its complications, how sociodemographic factors play a role in bringing a new array of anaemia components, and why culture-tailored programs might have a greater impact for vulnerable populations. Finally, highlights of Peru's Multisectorial Plan to Combat anaemia ("Plan Multisectorial de Lucha Contra la anaemia") will be shared, in order to bring an example of a current integrated program that involves further components, rather than just a usual supplementation procedure.

The extension of iron fortification programs in developing countries is confronted by several obstacles. For example, "the use of cereal-based programs depends not only on identifying a suitable vehicle but on a means of adding iron in a bioavailable form and in a manner that does not alter the color or taste of the food" (Cook, 1994, pg. 225), since if altered, people might not welcome the change. Additionally, the inhibiting effect of cereal-based diets on the absorption of nonheme dietary iron due to the presence of phytates. Furthermore, ascorbic acid is the most commonly added compound for the enhancement of iron absorption. However, 
“its sensitivity to heat (prolonged boiling, baking, and frying temperatures), water, and oxygen must be taken into consideration" (Hurrell et. al, 2004, pg. 390), signaling that proper packaging will have to be administered, which adds a significant cost for the final product. Researcher Lynch (2005) highlights that specific laboratory indicators of iron status should be implemented in developing countries to monitor the impact of interventions.

Sociodemographic status influences all aspects of a healthy lifestyle. If we recall the social determinants of health, access to either nutrition, health, education, or sanitary services is often restricted, especially for the most vulnerable. Economist Chong (2016) categorized IDA as part of a "nutrition-based poverty" trap, which is an economic model arguing that poverty plays an important role in how you feed yourself depending on what you have access to. Research done in periurban areas of Peru concluded that school attainment was based on the student's diet, where more anaemic students performed worse than their less anaemic counterparts. Correspondingly, another study by Gyorkos et al. (2004) identified that in order to improve iron intakes of pregnant women in the jungle region of Peru, "one should consider the causes of their dietary insufficiency" (Gyorkos et al., 2004, pg. 513). For these women, it was common to leave the nutritional parts for her husband and children, leaving her with the wings or feet of the poultry. Furthermore, in a different study by Chakrabarti et al. (2018), public health interventions to combat anaemia in pregnant women would be best approached from "a holistic perspective that simultaneously accounts for factors at multiple levels" (Chakrabarti et al., 2018, pg. 2424). These levels may include targeting women's education, the promotion of delayed marriage, construction and use of toilets, and measures that facilitate adoption of nutrient rich diets. 
The formative research by Galloway et al. (2002) identified an array of cultural beliefs across developing countries that act as barriers to iron supplementation. A culturally tailored approach was suggested to appeal to all kinds of populations. In the study by Seshan et al. (2018), a culturally-tailored nutrition education intervention program was designed to encourage behavior change through awareness of gestational anaemia, its risks, and the benefits of healthy food habits. The study revealed "a lack of culturally-sensitive antenatal educational sessions for antenatal women in developed and developing countries" (Seshan et al., 2018, pg. 328). To the contrary, having antenatal education units in hospitals will motivate mothers' response of care during pregnancy.

\section{“Plan Multisectorial de Lucha contra la anaemia" (2018)}

The "multisectorial plan to combat anaemia" proposes to articulate intersectorial and intergovernmental effective interventions, focusing primarily on involving the departments of Health, Education, Housing, Farming, Production, Culture, Women and Vulnerable Populations, Development and Social Inclusion, Finance and Economy, and Environment. The plan emphasizes that interventions should be strategically placed during the first year of life, given that it is a critical stage to intervene and achieve positive results against anaemia.

However, despite previous efforts in promoting vaccines for children that can prevent diarrhea, which also included health check ups for an effective development, only " $15 \%$ of children under 36 months have been recorded to take part on this program, and in the case of children less than one year, it's 26\%" (MEF, 2018). Similarly, many pregnant women have been offered the opportunity of a program where they receive four laboratory exams during the first 
trimester of pregnancy, four prenatal care appointments, and iron supplements, but only " $21 \%$ of pregnant women receive those services" (MEF, 2018).

Health resources have been offered, but not even $50 \%$ of children or pregnant women use them according to the shared statistics. One explanation is that in order to register for health services the individual has to have a valid ID, and many don't. Systemic barriers like this one can be overcome with a change in policy. Peru is culturally diverse, and problems that might exist on the coast may very well differ from those found in the highlands, or in various regions of the jungle. It is through this culturally diverse lense which public health must work to achieve a holistic and personalized approach for each of the targeted populations. I value the effort that the multisectorial plan of anaemia has put into involving multiple actors per contra relying on only iron supplementation. We cannot address iron-deficiency anaemia successfully under the one-size fits all model. 


\section{Conclusion}

It is important to recognize that iron-deficiency anaemia can be preventable, but current practices are failing in identifying the social conditions of anaemia. The use of iron supplements has illuminated a number of secondary effects contributing to non-compliance. Consumption of tea, coffee, and grain-based diets in most of the developing world means lower absorption of nonheme iron, in addition to low consumption of heme iron. What's more, access to antenatal care, complete consultations, and up-to-date equipment to accurately diagnose anaemia are pertinent factors when drafting an intervention. Likewise, adolescent pregnancy should be tackled from a more proactive angle than letting new inexperienced mothers decide when to seek care. Furthermore, multiparous women should be given personalized care and concrete information that their pregnancies are not going to have the same outcome, and they are at greater risk of developing iron-deficiency anaemia, especially if they are economically restricted. On top of everything, misconceptions of anaemia seem to be the biggest challenge, because women across cultures don't share a common understanding of anaemia, and therefore, it is not ascribed the significance it deserves.

Given the multiple determinants of anaemia in developing countries, I argued that analyzing iron deficiency under the lense of the social determinants of health leads us to an intervention that doesn't rely solely on iron supplementation, but is holistically and culturally sensitive. This is precisely what is needed to target sociodemographic factors, education, dietary factors, quality and prescription of iron supplements, and better direct cultural practices and understandings of anaemia. Equivalently, one of the midwives mentioned that to treat anaemia, a multisectorial plan that encompass all neonates, children under five years of age, adolescent 
women, and a rigorous prenatal control for pregnant women is necessary ("Que abarque a los niños recién nacidos, a los niños menores de cinco años, que incluya a los adolescentes, y que haga un control estricto en las mujeres embarazadas"). Only then we will be walking in the right direction toward a decrease in the incidence of anaemia.

Generally speaking, there is not an overarching protocol to diagnose or treat anaemia. For instance, hemoglobin measurements can be counterfeited by other bodily processes and therefore they are not accurate. Comparatively, fortification efforts for food staples are controversial, since every country has unique diet practices, and a change for one country cannot be expected to work effectively for everyone. A midwife argued that iron supplements should be given to all children and pregnant women, hemoglobin exam results notwithstanding, since a child is always going to need a multivitamin supplement, especially since we don't know how they are being fed at home ("No dependiendo de un examen de hemoglobina, porque tu sabes que, un niño siempre va a requerir un suplemento vitamínico, porque no sabemos cual es la alimentación en casa"). Indeed, a culturally sensitive approach that involves all social conditions of anaemia can guarantee the establishment of new ways of practicing health counseling and delivering important information, as well as improving follow-up for iron pills intake, revising guidelines of access to food and health services, and enhancing diet practices adjusted to the individual's budget, time, and location. Further research is necessary to identify the social conditions of anaemia innate of any targeted population, to then design a culturally-sensitive intervention protocol. 


\section{References}

Ailinger, R. L., Moore, J. B., Pawloski, L., \& Cortés, L. R. Z. (2009). Concepts of anemia among low income Nicaraguan women. Revista latino-Americana de enfermagem, 17(2), $147-152$.

Akramipour, R., Rezaei, M., \& Rahimi, Z. (2008). Prevalence of iron deficiency anemia among adolescent schoolgirls from Kermanshah, Western Iran. Hematology, 13(6), 352-355.

Balarajan, Y., Ramakrishnan, U., Özaltin, E., Shankar, A. H., \& Subramanian, S. V. (2011). Anaemia in low-income and middle-income countries. The lancet, 378(9809), 2123-2135.

Breymann, C. (2015, October). Iron deficiency anemia in pregnancy. In Seminars in hematology (Vol. 52, No. 4, pp. 339-347). WB Saunders.

Chakrabarti, S., George, N., Majumder, M., Raykar, N., \& Scott, S. (2018). Identifying sociodemographic, programmatic and dietary drivers of anaemia reduction in pregnant Indian women over 10 years. Public health nutrition, 21(13), 2424-2433.

Chong, A., Cohen, I., Field, E., Nakasone, E., \& Torero, M. (2016). Iron deficiency and schooling attainment in peru. American Economic Journal: Applied Economics, 8(4), $222-55$.

Chung, M., Chan, J. A., Moorthy, D., Hadar, N., Ratichek, S. J., Concannon, T. W., \& Lau, J. (2013). Biomarkers for Assessing and Managing Iron Deficiency Anemia in Late-Stage Chronic Kidney Disease: Future Research Needs: Identification of Future Research Needs From Comparative Effectiveness Review No. 83. 
Compaore, A., Gies, S., Brabin, B., Tinto, H., \& Brabin, L. (2014). “There is Iron and Iron...” Burkinabè Women's Perceptions of Iron Supplementation: A Qualitative Study. Maternal and child health journal, 18(8), 1976-1984.

Cook, J. D., Skikne, B. S., \& Baynes, R. D. (1994). Iron deficiency: the global perspective. In Progress in iron research(pp. 219-228). Springer, Boston, MA.

Denic, S., \& Agarwal, M. M. (2007). Nutritional iron deficiency: an evolutionary perspective. Nutrition, 23(7-8), 603-614.

Galloway, R., Dusch, E., Elder, L., Achadi, E., Grajeda, R., Hurtado, E., ... \& Moore, K. M. (2002). Women's perceptions of iron deficiency and anemia prevention and control in eight developing countries. Social science \& medicine, 55(4), 529-544.

Gyorkos, T. W., Shenker, H., Larocque, R., UGAZ, M. D. R., \& Gotuzzo, E. (2004). Sociodemographic and dietary correlates of anemia in pregnant women in Peru. Ecology of food and nutrition, 43(6), 497-516.

Hassan, R., Abdullah, W. Z., \& Hussain, N. H. N. (2005). Anemia and iron status of Malay women attending an antenatal clinic in Kubang Kerian, Kelantan, Malaysia. Southeast Asian journal of tropical medicine and public health, 36(5), 1304.

Hurrell, Lynch, Bothwell, Cori, Glahn, Hertrampf, ... \& Yeung. (2004). Enhancing the absorption of fortification iron: A SUSTAIN task force report. International journal for vitamin and nutrition research, 74(6), 387-401.

Instituto Nacional de Estadística e Informática (INEI). (2017b). Encuesta Nacional de Hogares ENAHO. Lima: INEI. 
Instituto Nacional de Estadística e Informática (INEI). (2018). Indicadores de resultados de los programas presupuestales 2012-2017. Lima: INEI.

Kadivar, M. R., Yarmohammadi, H., Mirahmadizadeh, A. R., Vakili, M., \& Karimi, M. (2003). Prevalence of iron deficiency anemia in 6 months to 5 years old children in Fars, Southern Iran. Medical Science Monitor, 9(2), CR100-CR104.

Lozoff, B., Beard, J., Connor, J., Barbara, F., Georgieff, M., \& Schallert, T. (2006). Long-lasting neural and behavioral effects of iron deficiency in infancy. Nutrition Reviews,64(5 Pt 2), S34-43.

Lynch, S. R. (2005). The impact of iron fortification on nutritional anaemia. Best Practice \& Research Clinical Haematology, 18(2), 333-346.

Lynch, S. R. (2011). Why nutritional iron deficiency persists as a worldwide problem. The Journal of nutrition, 141(4), 763S-768S.

Marmot, M., \& Allen, J. J. (2014). Social determinants of health equity.

Mengistu, G., Azage, M., \& Gutema, H. (2019). Iron Deficiency Anemia among In-School Adolescent Girls in Rural Area of Bahir Dar City Administration, North West Ethiopia. Anemia, 2019.

Menon, K. C., Ferguson, E. L., Thomson, C. D., Gray, A. R., Zodpey, S., Saraf, A., ... \& Skeaff, S. A. (2016). Effects of anemia at different stages of gestation on infant outcomes. Nutrition, 32(1), 61-65.

Miller, J. L. (2013). Iron deficiency anemia: a common and curable disease. Cold Spring Harbor perspectives in medicine, 3(7), a011866. 
Milman, N. (2011). Anemia—still a major health problem in many parts of the world!. Annals of hematology, 90(4), 369-377.

Ministerio de Economía y Finanzas (MEF). (2018). Base de datos analitica del Cubo Infant-SIS.

Ministerio de Desarrollo e Inclusión Social. (2018). Plan Multisectorial de lucha contra la Anemia. Hecho en el depósito legal en la Biblioteca Nacional del Perú N. ${ }^{\circ}$ 2018-13980.

National Heart, Lung and Blood Institute (NHLBI). (2011). In brief: Your Guide to Anemia. U.S. Department of Health and Human Services. Retrieved from https://www.nhlbi.nih.gov/files/docs/public/blood/anemia-inbrief yg.pdf

National Institutes of Health. (2019). Iron [Fact Sheet for Consumers]. U.S. Department of Health \& Human Services. Retrieved from https://ods.od.nih.gov/factsheets/Iron-Consumer/

Ohri-Vachaspati, P., \& Swindale, A. J. (1999). Iron in the diets of rural Honduran women and children. Ecology of food and nutrition, 38(3), 285-306.

Quezada Reyes, E. D., Pérez Ramírez, M. D. P., Huamán Mujica, K., Serrano Goicochea, A. I., \& Raza Vásquez, L. E. (2018). Conductas alimentarias de la madre relacionadas con prevalencia de anemia en menores de 5 años.

Ramírez-Luzuriaga, M. J., Larson, L. M., Mannar, V., \& Martorell, R. (2018). Impact of double-fortified salt with iron and iodine on hemoglobin, anemia, and iron deficiency anemia: a systematic review and meta-analysis. Advances in Nutrition, 9(3), 207-218.

Ru, Y., Pressman, E. K., Cooper, E. M., Guillet, R., Katzman, P. J., Kent, T. R., ... \& O’Brien, K. O. (2016). Iron deficiency and anemia are prevalent in women with multiple gestations. The American journal of clinical nutrition, 104(4), 1052-1060. 
Saha, L., Pandhi, P., Gopalan, S., Malhotra, S., \& Saha, P. K. (2007). Comparison of efficacy, tolerability, and cost of iron polymaltose complex with ferrous sulphate in the treatment of iron deficiency anemia in pregnant women. MedGenMed : Medscape general medicine, $9(1), 1$.

Samuel, T. M., Thomas, T., Finkelstein, J., Bosch, R., Rajendran, R., Virtanen, S. M., ... \& Duggan, C. (2013). Correlates of anaemia in pregnant urban South Indian women: a possible role of dietary intake of nutrients that inhibit iron absorption. Public health nutrition, 16(2), 316-324.

Scholl, T. O. (2005). Iron status during pregnancy: setting the stage for mother and infant. The American journal of clinical nutrition, 81(5), 1218S-1222S.

Seshan, V., Alkhasawneh, E., Al Kindi, S., Al Simadi, F. A. M., \& Arulappan, J. (2018). Can gestational anemia be alleviated with increased awareness of its causes and management strategies? implications for health care services. Oman medical journal, 33(4), 322.

Stephen, G., Mgongo, M., Hussein Hashim, T., Katanga, J., Stray-Pedersen, B., \& Msuya, S. E. (2018). Anaemia in pregnancy: Prevalence, risk factors, and adverse perinatal outcomes in Northern Tanzania. Anemia, 2018.

Susanti, A. I., Sahiratmadja, E., Winarno, G., Sugianli, A. K., Susanto, H., \& Panigoro, R. (2017). Low hemoglobin among pregnant women in midwives practice of primary health care, Jatinangor, Indonesia: iron deficiency anemia or $\beta$-thalassemia trait?. Anemia, 2017.

WHO. (2020). Graph of prevalence of anaemia in children under 5 years (\%) in 2015. "Reprinted from the Global Health Observatory,"Geneva: World Health Organization. Retrieved from https://www.who.int/data/gho/data/indicators. 
WHO. (2020). Graph of prevalence of anaemia in women of reproductive age (\%) in 2015.

“Reprinted from the Global Health Observatory," Geneva: World Health Organization. Retrieved from https://www.who.int/data/gho/data/indicators.

WHO. (2020). Graph of prevalence of anaemia in non-pregnant women (\%) in 2015.

"Reprinted from the Global Health Observatory," Geneva: World Health Organization.

Retrieved from https://www.who.int/data/gho/data/indicators

WHO. (2020). Graph of prevalence of anaemia among pregnant women (\%) in 2015. "Reprinted from the Global Health Observatory," Geneva: World Health Organization. Retrieved from https://www.who.int/data/gho/data/indicators.

WHO. (2020). Social determinants of health: About social determinants of health. Geneva: World Health Organization. Retrieved from https://www.who.int/social determinants/sdh_definition/en/

WHO. (2015). The global prevalence of anaemia in 2011. Geneva: World Health Organization, (NLM classification: WH 155).

Wilunda, C., Yoshida, S., Blangiardo, M., Betran, A. P., Tanaka, S., \& Kawakami, K. (2018). Caesarean delivery and anaemia risk in children in 45 low-and middle-income countries. Maternal \& child nutrition, 14(2), e12538. 


\section{Appendix A}

Table 3. Prevalence of anaemia in children under 5 years (\%) in 2015

$\begin{array}{ll}\text { Regions } & (\mathbf{\%}) \\ \text { Africa } & 59.71 \\ \text { Americas } & 22.26 \\ \text { South-East Asia } & 51.61 \\ \text { Europe } & 21.45 \\ \text { Eastern Mediterranean } & 45.32 \\ \text { Western Pacific } & 21.29\end{array}$

Note: Graph of prevalence of anaemia in children under 5 years (\%) in 2015. "Reprinted from the Global Health Observatory," by WHO, 2020. Retrieved from https://www.who.int/data/gho/data/indicators. Reprinted with permission.

Table 4. Prevalence of anaemia in women of reproductive age (\%) in 2015

$\begin{array}{ll}\text { Regions } & \mathbf{( \% )} \\ \text { Africa } & 38.8 \\ \text { Americas } & 18.44 \\ \text { South-East Asia } & 45.3 \\ \text { Europe } & 21.8 \\ \text { Eastern Mediterranean } & 39.09 \\ \text { Western Pacific } & 23.93\end{array}$

Note: Graph of prevalence of anaemia in women of reproductive age (\%) in 2015. "Reprinted from the Global Health Observatory," by WHO, 2020. Retrieved from https://www.who.int/data/gho/data/indicators. Reprinted with permission.

Figure 5. Prevalence of anaemia in non-pregnant women (\%) in 2015

$\begin{array}{ll}\text { Regions } & \mathbf{( \% )} \\ \text { Africa } & 37.99 \\ \text { Americas } & 18.17 \\ \text { South-East Asia } & 45.17 \\ \text { Europe } & 21.66 \\ \text { Eastern Mediterranean } & 38.98 \\ \text { Western Pacific } & 23.68\end{array}$

Note: Graph of prevalence of anaemia in non-pregnant women (\%) in 2015. "Reprinted from the Global Health Observatory," by WHO, 2020. Retrieved from https://www.who.int/data/gho/data/indicators. Reprinted with permission. 
Table 6. Prevalence of anaemia in pregnant women (\%) in 2015

\section{Regions}

Africa

Americas

South-East Asia

Europe

Eastern Mediterranean

Western Pacific

\section{(\%)}

46.34

25.28

47.92

26.15

40.57

32

Note: Graph of prevalence of anaemia among pregnant women (\%) in 2015. "Reprinted from the Global Health Observatory," by WHO, 2020. Retrieved from https://www.who.int/data/gho/data/indicators. Reprinted with permission. 


\section{Appendix B}

Location: First and Second Tier Hospitals

Interview Questions for Midwives in Peru

Questions:

1. Anaemia in women of reproductive age (15-49) is associated with complications such as hemorragies, placental abruption, preterm birth, and low birth-weight. What is the incidence of anaemia in patients that you have attended or treated? [La anemia en mujeres de edad reproductiva (15-49) están asociadas con complicaciones como hemorragias, desprendimiento prematuro de la placenta o placenta abrupta, nacimiento prematuro, y bajo peso del recién nacido. Cuál es la incidencia de pacientes con anemia que usted ha tratado o atendido?]

2. Have you noticed that the incidence of anemia among pregnant women that come from the rural part of the country is higher than their counterparts that lived in the urban areas? [Ha notado más incidencia de anemia en mujeres que vienen de la parte interior del país?]

3. Have pregnant women that have been treated in this hospital been informed about taking folic acid or iron supplements? Do you know the percentage of pregnant women that are aware of such supplements? [Pacientes gestantes que se atienden en este hospital han sido aconsejados de tomar ácido fólico o suplementos de hierro durante los meses de embarazo? Y cuál es el porcentaje de mujeres embarazadas que saben que tienen tomar estos suplementos?]

4. Which one will you say is the primary cause of anaemia in pregnant women (general estimate or from the hospital)? [Cuál diría usted es la causa principal de anemia en madres gestantes (en general o del hospital)?]

5. Are adolescent pregnancies at a higher risk of being anaemic than non-adolescent? Why is that? Does the number compare to the rest of the pregnant women who are not adolescents? [Cuántos embarazos adolescentes tienden a correr el riesgo de ser anémicos? Y por qué? Se compara con el resto de gestantes no adolescentes?] 
6. Do you know of any complications or secondary effects when taking iron supplements? Are the patients informed about them? [Conoce algunas de las complicaciones o efectos secundarios al tomar los suplementos de hierro? Le informan a la pacientes?]

7. Have you heard of the practice "delay clamping of the placenta" ( 2 to $3 \mathrm{~min}$ ) as a method to reduce the risk of anemia in infants? Is this part of your current practice? [Ha escuchado de la práctica de corte de cordón tardío (2 a 3 min) para disminuir la incidencia de anemia. Usted lo practica?]

8. Have you heard of the "multisectorial plan" against anaemia? What is your opinion about that? [Sabe sobre el Plan Multisectorial en contra de la anemia? Cuál es su opinión? 